\title{
Microbiota dysbiosis and barrier dysfunction in inflammatory bowel disease and colorectal cancers: exploring a common ground hypothesis
}

\author{
Linda Chia-Hui Yu(D
}

\begin{abstract}
Inflammatory bowel disease (IBD) is a multifactorial disease which arises as a result of the interaction of genetic, environmental, barrier and microbial factors leading to chronic inflammation in the intestine. Patients with IBD had a higher risk of developing colorectal carcinoma (CRC), of which the subset was classified as colitis-associated cancers. Genetic polymorphism of innate immune receptors had long been considered a major risk factor for IBD, and the mutations were also recently observed in CRC. Altered microbial composition (termed microbiota dybiosis) and dysfunctional gut barrier manifested by epithelial hyperpermeability and high amount of mucosa-associated bacteria were observed in IBD and CRC patients. The findings suggested that aberrant immune responses to penetrating commensal microbes may play key roles in fueling disease progression. Accumulative evidence demonstrated that mucosa-associated bacteria harbored colitogenic and protumoral properties in experimental models, supporting an active role of bacteria as pathobionts (commensal-derived opportunistic pathogens). Nevertheless, the host factors involved in bacterial dysbiosis and conversion mechanisms from lumen-dwelling commensals to mucosal pathobionts remain unclear. Based on the observation of gut leakiness in patients and the evidence of epithelial hyperpermeability prior to the onset of mucosal histopathology in colitic animals, it was postulated that the epithelial barrier dysfunction associated with mucosal enrichment of specific bacterial strains may predispose the shift to disease-associated microbiota. The speculation of leaky gut as an initiating factor for microbiota dysbiosis that eventually led to pathological consequences was proposed as the "common ground hypothesis", which will be highlighted in this review. Overall, the understanding of the core interplay between gut microbiota and epithelial barriers at early subclinical phases will shed light to novel therapeutic strategies to manage chronic inflammatory disorders and colitis-associated cancers.
\end{abstract}

Keywords: Colitis, colorectal cancers, intestinal dysbiosis, barrier function, epithelial permeability, bacterial internalization

\section{Introduction}

Human intestine harbors approximately $3.8 \times 10^{13}$ bacteria, with over 1000 species found in a cohort [1]. Bacteria also habitat the skin, oral and nasal cavity, and vagina; however, the bacterial counts in extraintestinal organs are no more than $10^{12}[1,2]$. Along with the large amount of bacteria, other microorganisms including virus,

\section{Correspondence: Ichyu@ntu.edu.tw}

Graduate Institute of Physiology, National Taiwan University College of Medicine, Suite 1020, \#1 Jen-Ai Rd. Sec. 1, Taipei 100, Taiwan, Republic of China

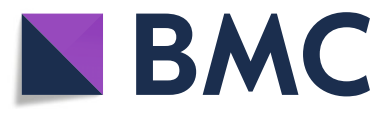

archaea, and fungi inhabits the gastrointestinal tract and are collectively defined as the gut microbiota [3]. Keeping in mind that the number of gut bacteria is the same order as human cells and the bacterial genes outnumber human genes by 10- to 100- fold, a symbiotic relationship is maintained between the host and the lumen-confined microbes in a healthy state [4]. Recent evidence indicated that altered microbial communities (termed "microbiota dysbiosis") and intestinal barrier impairment are associated with the development of a number of chronic inflammatory disorders and systemic diseases [5-7]. These included

(c) The Author(s). 2018 Open Access This article is distributed under the terms of the Creative Commons Attribution 4.0 International License (http://creativecommons.org/licenses/by/4.0/), which permits unrestricted use, distribution, and reproduction in any medium, provided you give appropriate credit to the original author(s) and the source, provide a link to the Creative Commons license, and indicate if changes were made. The Creative Commons Public Domain Dedication waiver (http://creativecommons.org/publicdomain/zero/1.0/) applies to the data made available in this article, unless otherwise stated. 
inflammatory bowel disease (IBD), celiac disease, multiple sclerosis, rheumatoid arthritis, ankylosing spondylitis, psoriasis, type 2 diabetes, allergic diseases, cardiovascular and neurodegenerative diseases, and cancers [8-13]. An incoming speculation of common factors involved in the pathogenesis of chronic polygenic disorders has been proposed as the "common ground hypothesis", which placed microbiota dysbiosis and leaky gut in the core mechanisms of a wide array of diseases.

The breach of mucosal barrier may result in unlimited passages of microbes to lamina propria and systemic bloodstream, which could overturn immune tolerance to hyperactivation in the body. The epithelial barrier defects accompanied by an altered microbial community were observed in patients and experimental models of chronic and acute intestinal diseases, such as IBD (Crohn's disease (CD) and ulcerative colitis (UC)) [1417], celiac disease[18-22], bowel obstruction [23-25], and gastrointestinal (GI) infection [26-29]. IBD is a multifactorial disease of unclear etiology, which arises as a result of the interaction of genetic, environmental, barrier and microbial factors leading to immunological responses and chronic inflammation in the intestine. Patients with IBD had a higher risk of developing colorectal carcinoma (CRC) in later life [30]. As genetic polymorphisms of innate immune receptors (such as nucleotide-binding oligomerization domain (NOD) 2/ CARD15 and toll-like receptor (TLR) 4 [31-35]) are considered major risk factors for IBD development, aberrant immune response to host own commensal microbiota was considered to play key roles in fueling the progression of inflammatory diseases. Recent evidence demonstrated that immune-related gene mutations were also observed in CRC patients, including polymorphism in TLRs and ATG16L1 (an autophagy gene for control of immune responses to virus and bacteria) [36-38]. Experimental models provided evidence that aberrant epithelial innate immune responses were involved in the pathogenesis of colitis and tumor development [39-43], further supporting a link between microbe, inflammation and cancers.

The purpose of the review is to summarize the evidence of bacterial dysbiosis and barrier dysfunction in patients and experimental models of IBD and CRC, and to discuss the "common ground hypothesis" to explain abnormal host-microbe interactions underlying disease pathogenesis. Lastly, this review offers further speculation on the mechanisms of mucosal enrichment and conversion of commensal-derived pathobionts in the context of inflammation and cancers.

\section{Microbiota dysbiosis and mucosa-associated bacteria in chronic inflammation}

Microbiota dysbiosis is characterized by microbial population, diversity, spatial, or number change in the human body $[9,43]$. Stool samples are often used as surrogates for the intestinal microbial contents because it is relatively easy to collect in clinical laboratories. Distinct fecal microbial communities were found between IBD patients and healthy control subjects [44-46]. An average of $25 \%$ less microbial richness was found in IBD patients compared to healthy individuals [47-49]. The reduction of microbial diversity with relative abundance or paucity of specific bacterial taxa was widely reported in IBD patients. However, a large variation of fecal bacterial composition in IBD patients was documented in the literatures $[50,51]$.

An inter-individual variability was readily noted in the fecal microbiota of healthy subjects. Although over one thousand bacterial species were identified in a cohort study with mainly four phyla (Bacteroidetes, Firmicutes, Proteobacteria and Actinobacteria), it should be emphasized that each person harbors around 160 species and that only 30-40 species as the bulk of microbiota are shared among individuals [48, 52, 53]. Studies with Crohn's patients have shown that Enterobacteriaceae family [54, 55], and Fusobacterium and Enterococcus faecalis [56] were significantly increased in the fecal samples compared to those of healthy subjects. Lower bifidobacterial populations and reduction of butyrateproducing bacteria (such as Faecalibacterium, Eubacterium, Roseburia, Lachnospiraceae and Ruminococcaceae) were found in fecal samples of patients with CD and UC $[55,57-59]$. Despite variable results were documented, a reduction of fecal bacterial richness were commonly reported in patients with CD and UC [60-63]. This suggests that maybe fewer species could be making up the majority of a disease-associated microbial population.

While a general consensus exists that altered gut microbiota composition is associated with IBD, a direct causal relationship remains debatable in humans. The uncertainty of causation or correlation is partly due to the fact that stool samples are collected at one single time point in patients (after the diagnosis of IBD) and in healthy subjects without the disorder. Other confounding factors include the dietary habits and life style in individuals, and the use of antibiotics and immunotherapy in patients. Hence, the timing of bacteria dysbiosis relative to disease onset is hard to decipher in humans even by studies of pediatric cohorts [64-66]. The cause-effect relationship of microbiota dysbiosis and chronic inflammatory disorders relied mainly on data of experimental models.

Accumulating evidence indicated that mucosa-associated bacteria are different from fecal microbial population, and may better reflect regional changes in gut microbes at mucosal surfaces at sites of inflammation $[50,53]$. In healthy states, indigenous symbiotic bacteria mostly reside in the intestinal lumen which are separated 
from the epithelial cells by inner firm mucus layers [67], and are not in direct contact with the epithelial cells in physiological conditions [68, 69]. Nevertheless, high densities of mucosa-associated bacteria were reported in IBD patients $[64,65,70]$, and were suspected to play a more dominant role than fecal microbiota in promoting gut inflammation. A recent study demonstrated that microbiota obtained from IBD patients from a greater mass of biofilm containing bacteria and extracellular matrix compared to that of healthy controls [71]. Moreover, higher invasiveness of IBD biofilms in a model of human intestinal epithelia was observed compared to healthy control biofilms, demonstrating a more virulent phenotype of microbiota in IBD patients [71].

The enrichment of Enterobacteriaceae, Bacteroides/ Prevotella, Veillonellaceae, and Fusobacteriaceae were reported in ileal and colonic biopsies of new-onset treatment-naïve pediatric patients with CD and UC [6466]. Other studies showed the abundance of the Escherichia coli in tissue biopsies of Crohn's patients [55, 60, 72-74]. In addition, adherent-invasive E.coli (AIEC) was found in the ileal lesions of Crohn's disease patients [72, 75]. Moreover, a high amount of adherent Bacteroides fragilis was found in the mucosal biofilm in patients with IBD [64]. Presence of $B$. fragilis and enterotoxigenic $B$. fragilis (ETBF) was found in the stool and biopsy specimens of healthy individuals, but significantly higher toxin genes were detected in UC patients [76-78]. Furthermore, Enterococcus strains with adherent and biofilm-forming ability were isolated from tissue biopsies of IBD patients [79]. Taken together, abundance of mucosa-associated bacteria is correlated to gut inflammation.

The role of gut microbiota in colitis development was confirmed by using animal models. Germ-free mice displayed minimal inflammation or delayed onset of chemically and genetically induced colitis (e.g. IL-2(-/-) and IL-10(-/-)) compared to the conventionally raised animals [80-84]. However, higher mortality was seen in germ-free than conventional mice after giving dextran sulfate sodium (DSS) due to massive gut epithelial injury $[82,83]$. The seemingly paradoxical phenomenon could be explained by the lack of immune maturation and/or tolerance as well as the impairment of epithelial turnover (which is dependent on commensal colonization) in germ-free intestine [85-87]. With this said, germ-free models provided clear evidence that intestinal bacteria are crucial for the development of colitis. Other studies using co-housing and fecal transplantation experiments demonstrated the existence of "disease-predisposing microbiota" or "pathobionts" (an opportunistic bacteria derived from commensals) in the fecal microbiota $[88,89]$. The animal experiments supported that intestinal bacteria played a disease-predisposing role in colitis development.
Recent studies by using monoassociation and inoculation experiments have helped teased out the roles of single strains of colitis-associated bacteria, and provided valuable information in addition to the overall dysbiotic microbiota. The gut bacterial species documented with pro-inflammatory roles are discussed in the following sections along with the underlying colitogenic mechanisms.

\section{Escherichia coli}

High levels of mucosa-associated bacteria with adherence and invasive ability were isolated from Crohn's disease patients [72, 75]. Oral inoculation of Crohn's associated AIEC (LF82 strain), but not the human laboratory E.coli $\mathrm{K}-12$, resulted in severe colitis in transgenic mice overexpressing human carcinoemcryonic antigen adhesion molecule 6 (CEACAM6, a receptor to type 1 pili or fimbriae) [90]. In contrast, AIEC did not colonize nor induce colitis in wild type mice [90]. The colitogenic activity of AIEC was dependent on type 1 pili expression as bacteria deleted of the fimH gene failed to induce mucosal inflammation [90].

There are evidence indicated that virulence factors other than fimbriae may be crucial for the colitogenic effects. It is noteworthy that the fimH protein sequence of E.coli K-12 strain showed high degree of homology (97\%) to the LF82, and it only differed from LF82 by variations at residues Ala-48, Ser-91, and Asn-99 [91]. Moreover, the adherence and invasive ability of fim-mutants of LF82 was restored to wild type levels by transforming a fim operon derived from $E$. coli $\mathrm{K}-12$ to the mutant. The finding suggested that the fimbriae synthesized by K-12 also possess adherence properties despite of inability of promoting inflammation. In contrast, a non-invasive laboratory E.coli strain JM109 transformed with fim operons derived from LF82 or K-12 strains did not gain invasive properties, suggesting that although fimbriae-mediated adherence may facilitate bacterial invasion but is insufficient to cause translocation by itself [91]. Additional mechanisms of Crohn's associated AIEC related to its colitogenic ability included higher bacterial survival and replication inside macrophages and induction of proinflammatory cyclooxygenase (COX)-2 expression from macrophages [92, 93]. Recent data also showed that AIEC LF82 strain is capable of long term intracellular survival in gut epithelial cells by suppressing autophagy [94-96], which could contribute to long-term infection.

Other studies showed that monoassociation of nonpathogenic E.coli and Enterococcus faecalis to gnotobiotic IL-10(-/-) mice induced inflammation in the cecum and distal colon, respectively [81]. Dual-association of the two commensal bacteria in gnotobiotic IL-10(-/-) induces aggressive pancolitis and duodenal inflammation [97, 98]. 
The findings demonstrated that commensal bacteria isolated from healthy subjects could be colitogenic when monoassociated in mice with genetic deficiency but not in wild type mice, suggesting that opportunistic commensals may turn into pathobionts in genetically-predisposed hosts.

\section{Bacteroides subspecies}

Commensal Bacteroides spp., such as B. fragils and B. vultagus, have been reported to modulate colitis development. Abundance of enterotoxigenic B. fragilis (ETBF) was detected in the stool and biopsy specimens of UC patients [76-78]. ETBF but not its nontoxigenic strain causes persistent colitis after oral inoculation to wild type mice [99] and a more severe form of inflammation in models of chemically induced colitis [100]. Intestinal permeability was increased and epithelial E-cadherin was cleaved in vivo in the ETBF-colonized wild type mice [101]. The enterotoxin produced by B. fragilis (also known as fragilysin) acted as a metalloprotease for cleavage of junctional protein and induction of epithelial-derived IL-8 synthesis, which were suggested to be involved in the colitogenic ability [102, 103]. Moreover, gnotobiotic mice monoassociated with three strains of B. vultagus isolated from UC patients showed exacerbated cecal inflammation after DSS administration [104], suggesting potential pro-inflammatory ability of the bacteria.

\section{Enterococcus species}

Increased colonic inflammation was observed in IL-10(-/-) mice after inoculation or monoassociation with Enterococcus faecalis and E. faecium [105-107]. The colitogenic characteristics of $E$. faecalis was partly attributed to a bacterial gelatinase which was involved in intestinal barrier impairment and degradation of E-cadherin (a junctional protein) in mouse studies [106]. Moreover, bacterial adherence and penetration to mucosal layers and biofilm formation of $E$. faecalis were dependent on an enterococcal polysaccharide antigen [107]. A cell surface-associated lipoprotein on E. faecalis stimulated TLR2-mediated dendritic cell activation and contributes to inflammation [107].

In sum, animal models have provided clear evidence of a disease-predisposing role of certain gut bacteria, yet whether the altered bacterial population is involved in the initiation or perpetuation of intestinal inflammation remains debatable. Moreover, mucosa-associated adherent and invasive bacteria may play a more pathogenic role than fecal microbes in IBD progression. The conversion mechanisms and timing of specific commensal bacteria to turn into invasive or colitogenic pathobionts have yet to be determined. Overall, longitudinal investigation of mucosa-associated bacterial changes that represents a smaller pool of gut microbiota may help elucidate the driver or passenger roles of individual microbes for colitis development.

\section{Microbiota dybiosis and mucosal biofilms in colon cancers}

Colon carcinoma is the second most commonly diagnosed cancer. The majority (60-85\%) of CRC is classified as sporadic cancers and around $10-30 \%$ is familial or hereditary, stressing the importance of environmental and microbial factors in tumorigenesis [108, 109]. IBD accounts for $1-2 \%$ of CRC cases, but the cancer risk in $\mathrm{UC}$ patients is 5 times higher than the general population and colitis-associated CRC is more aggressive [110]. The hereditary CRC which accounts for $<5 \%$ of CRC cases have identifiable germline mutation, such as adenomatous polyposis coli (APC) tumor suppressor gene [109]. Patients with APC gene mutation develop hundreds to thousands of colorectal polyps at young age, of which the disease is termed familial adenomatous polyposis (FAP). The FAP patients had a 100\% cumulative risk of progression to CRC by the age of 40 years, If the polyps were left untreated $[111,112]$. To date, abundant studies have revealed altered fecal microbiota composition and enrichment of mucosa-associated bacteria in patients with CRC or FAP [113-116].

Recent evidence indicated that mucosa-associated bacterial population may play more dominant roles than fecal microbiota in colon carcinogenesis [116-118]. Overabundance of $E$. coli was noted in tumor biopsies in stage I to IV CRC samples, whereas Fusobacterium nucleatum was found in stage IV but not in earlier stages of cancers $[119,120]$. A recent report showed that more than $50 \%$ of FAP patients harbor colonic biofilm with both E. coli and Bacteroides fragilis [113]. So far, these bacterial strains have been proposed as protumoral pathobionts based on experimental data of animal models.

The experimental models to investigate the roles of bacteria in colon carcinogenesis included conventionalized, germ-free, and gene-modified animals [121]. Studies of verifying an infectious carcinogen in conventionalized wild type situation would bear more resemblance to the heterogeneous population of human CRC. The benefits and caveats of each of these models are highlighted here. It is worth mentioning that commensal-derived pathobionts usually do not colonize well in a healthy gut with a diversified ecosystem. Many studies with bacterial inoculation experiments in conventionalized animals incorporated an antibiotic pretreatment protocol to overcome colonization resistance. However, the antibiotic regimen and the time frame of bacterial colonization varied in different reports [121]. The value of germ-free models is clearly seen as it would facilitate intestinal colonization or monoassociation of inoculated bacteria in a chronic 
setting of malignant transformation. Nevertheless, cautions were raised regarding the lack of intestinal and systemic immune maturation and/or tolerance in germ-free animals which might confound data interpretation [85-87]. Gene-modified mice that developed spontaneous colorectal cancers were also utilized to verify the hypothesis of protumoral bacteria, including $\operatorname{APC}(\mathrm{Min} /+)$ mice $[117,122,123]$ and mice deficient of NOD-like receptors $[88,89,124,125]$. There are criticisms of using gene-modified or immune-deficient mice which already had a distinct gut microbiota as a result of altered host genetics, and the clinical implication may be limited to only subsets of patients. While the research values of germ-free and gene-modified animals are undoubtful, it is still difficult to tease out the temporal order of host abnormality versus bacterial dysbiosis in these models. The potential tumorigenic bacterial strains are discussed below.

\section{Escherichia coli}

Despite indication of Crohn's-associated AIEC triggering intestinal inflammation by using transgenic mice overexpressing human CEACAM6 [90], no direct evidence was shown for the involvement of AIEC in cancer development. The induction of local inflammation by AIEC has been implicated as a link for progression to intestinal malignancy. Another report demonstrated an increase in tumor susceptibility in CEACAM6-transgenic mice after AOM treatment [126], suggesting a role of fimbriae (without specifying the bacterial strains) in colon tumorigenesis.

Clinical studies showed that $40 \%$ of mucosa-associated E.coli from IBD patients, and $67-86 \%$ of mucosa-associated E. coli obtained from CRC or diverticulosis specimens harbored the pks pathogenicity island encoding genotoxic coilbactin [117, 127]. Inoculation of NC101 strain (a mouse isolate of pks-positive E.coli) increased colon inflammation and intestinal crypt proliferation in human CEACAM6-transgenic mice [127], and caused DNA damage in colonocytes and promoted tumor growth in AOM-treated IL-10(-/-) mouse models $[117,123]$. Recent data demonstrated that monoassociation of pks-positivie $E$. coli increased the tumor burden in gnotobiotic $\mathrm{APC}(\mathrm{Min} /+)$ mice and $\mathrm{APC}(\mathrm{Min} /+)$; IL-10(-/-) mice [128]. Moreover, a clinical isolate CCR20 strain (a pks-positive E. coli obtained from human CRC samples) induced cellular senescence and increased tumor burden in AOM-treated IL-10(-/-) mouse models[129, 130]. Furthermore, the human CRC-associated E.coli triggered macrophage-derived COX-2 production in vitro in a $p k s$-independent manner [93], suggesting a genotoxin-independent, immune-mediated mechanism for the protumoral activity of bacteria.

\section{Enterotoxigenic Bacteroides fragilis}

Presence of ETBF was identified in mucosal biopsies of $60 \%$ of FAP patients in contrast to $30 \%$ in control individuals [113]. Higher amount of ETBF and B. fragilis toxin were observed in late-stage CRC samples [77, 78, 131]. Previous studies demonstrated that colonization of ETBF but not its non-toxigenic counterparts induced chronic colitis and promoted colon tumorigenesis in $\mathrm{APC}(\mathrm{Min} /+)$ mice $[118,122]$. A number of tumorigenic mechanisms of $B$. fragilis toxin have been proposed. B. fragilis toxin triggered an inflammatory protumoral signaling caspase in colonic epithelial cells that caused the recruitment of polymorphonuclear immature myeloid cells to promote colon cancers [132]. Other studies indicated that $B$. fragilis toxin may cause oxidative DNA damage or induce epithelial E-cadherin cleavage for barrier disruption [99, 101, 118]. Moreover, ETBF drives Th17 inflammation and also promoted invasion of pks-positive $E$. coli by causing mucus degradation in AOM-treated wild type mice [113, 122]. The findings indicated that synergistic effects of various strains of bacteria in immunomodulation may be involved in promoting colon tumorigenesis.

\section{Fusobacterium nucleatum}

Abundance of Fusobacterium DNA was observed in tumor tissues positively associated with poor prognosis in cancer patients [133]. Higher tumor burden was demonstrated in $\mathrm{APC}(\mathrm{Min} /+)$ mice following inoculation of clinical isolates of $F$. nucleatum, and was associated with activation of TLR4/MyD88/NFKB signaling and recruitment of tumor-infiltrating myeloid cells [116, 119]. One report showed that $F$. nucleatum did not induce colitis nor exacerbated colon inflammation in $\mathrm{APC}(\mathrm{Min} /+)$ mice [116]. In addition, inoculation of $F$. nucleatum did not aggravate intestinal inflammation nor induce tumors in colitic models of IL-10(-/-) and T-bet(-/-)/Rag2(-/-) mice [116]. The findings indicated that inflammation was not involved in the pathogenesis of Fusobacteria-mediated tumor progression.

Virulence factors and invasiveness of $F$. nucleatum have been implicated in promoting colon tumorigenesis. Higher transcript levels of FadA (an adhesin of F. nucleatum) was identified in carcinoma samples compared to normal mucosal biopsies or adenoma tissues [134]. Xenograft studies in immunodeficient mice have shown that injection of purified FadA protein into the subcutaneously inoculated sites resulted in larger tumor size [134]. Moreover, the invasive characteristic of $F$. nucleatum has been linked to cancer growth. In vitro studies demonstrated that FadA-dependent adherence and invasion of $F$. nucleatum was involved in induction of cell hyperproliferation, and FadA binding to 
E-cadherin induced nuclear translocation of $\beta$-catenin for oncogene transcription in human CRC cell lines [134]. Another study indicated that F. nucleatum invasion activated a TLR4/PAK-1 cascade for $\beta$-catenin signaling in CRC cell lines [135]. Lastly, FadA also enhanced the $E$. coli invasion in endothelial cell lines by using transwell assays [134, 136], further indicating that interaction between bacteria may be cause pathology to the hosts.

\section{Gut barrier dysfunction in chronic inflammation}

Gut leakiness manifested by epithelial hyperpermeability was long documented in CD [137-139] and UC patients [140-142]. Increased macromolecular flux in the intestine has been suggested as a predictor for inflammatory relapse in IBD patients in remission [143, 144]. Experimental models using chemical-induced colitis or genetic deficient mice which develop spontaneous enterocolitis with higher susceptibility to tumor formation have demonstrated that epithelial barrier dysfunction preceded the onset of mucosal inflammation [145-147]. An elegant study showed that mice expressing a dominant negative $\mathrm{N}$-Cadherin mutant lacking an extracellular domain (loss of endogenous E-cadherin) developed histopathological features of Crohn's disease by 3 months of age [148], supporting that epithelial barrier disruption was a cause for intestinal inflammation. Other reports documented that inhibition of epithelial hyperpermeability attenuated the colitis severity in animal models, providing further evidence of the cause-and-effect relationship [149, 150]. In sum, the loss of gut barrier integrity is an early event which contributes to chronic inflammation.

The gut barrier is composed of a single layer of epithelial cells which display densely-packed microvilli (brush border, $\mathrm{BB}$ ) rooted on terminal webs and are joined at their apical side by tight junctions (TJs) [151-153]. Among the epithelial ultrastructures, the apical BB formed by cytoskeletons separated bacteria from the cellular soma and acted as the transcellular barrier; the TJs formed the most marrow paracellular space and acted as the paracellular barrier. The TJ opening is regulated by activation of myosin light chain kinase (MLCK). In pathological conditions, bacteria may translocate across the epithelial layers through either transcellular or paracellular pathways (Fig. 1).

Both transcellular hyperpermeability (manifested by bacterial internalization to epithelia $[154,155])$ and paracellular hyperpermeability (evidenced by abnormal TJ expression and upregulated MLCK activity [156-160]) were noted in mucosal biopsies of patients with CD and UC. While low to negligible amount of bacteria was detected in mucosal tissues of control subjects, presence of mucosal bacteria was found in $83 \%$ of colonic specimens from the UC patients, in $56 \%$ of the ileal and in $25 \%$ of the colonic specimens from the CD patients [65]. Other reports showed 5- and 14-fold higher invasiveness of microbiota biofilms obtained from CD and UC patients, respectively, into a human model of intestinal epithelia, compared to those of healthy control biofilms [71]. Several strains of bacteria, including E. coli, E. faecalis B. vultagus, Fusobacterium varium isolated from $\mathrm{CD}$ or UC patients were found to invade epithelial cells in vitro $[107,155,161]$. Taken together, host barrier defects and microbial invasiveness were both documented in IBD patients.

Other than the transcytotic route, paracellular bacterial influx following $\mathrm{TJ}$ disruption was also observed in in vitro epithelial cultures [162-166]. However, the timing of two pathways (transcellular versus paracellular) was variable depending on the types of triggers in the context-specific models. To date, longitudinal studies that identify the time points of transcellular and paracellular barrier defects in animal models of colitis are still lacking. More studies are needed to decipher the timeline of epithelial barrier impairment and microbiota composition changes during the early course of colitis development.

Previous studies from our laboratory demonstrated that increased bacterial internalization to epithelial cells occurred prior to the onset of TJ damage using mouse models of bowel obstruction and superbug infection [24, 26, 67, 167]. It is believed that upon TJ destruction, luminal bacteria without strain specificity could flow freely through the paracellular space to underlying lamina propria and cause mucosal inflammation. On the other hand, only particular bacterial strains (such as Escherichia, Staphylococcus, Bacteroides) have been reported "inside" epithelial cells in our disease models of bowel obstruction and superbug infection $[24,26]$. It is possible that the strain-specific bacterial internalization and intracellular survival may act as an initial trigger to evoke damage to paracellular junctional structures, leading to non-specific bacterial translocation and colitis development. The impact of bacterial internalization on epithelial cytoskeletal structures and perijunctional organization has yet to be explored. Furthermore, whether the mucosa-association of bacteria as an early event in transcellular barrier dysfunction may alter the fecal microbiota due to preferential "anchoring" advantage warrants further investigation.

\section{Common ground hypothesis and further postulation}

Disease-predisposing microbiota was found in a wide spectrum of chronic disorders, including IBD and CRC [8-12]. These findings have led to the speculation of a common factor in multigenic disease development. A 


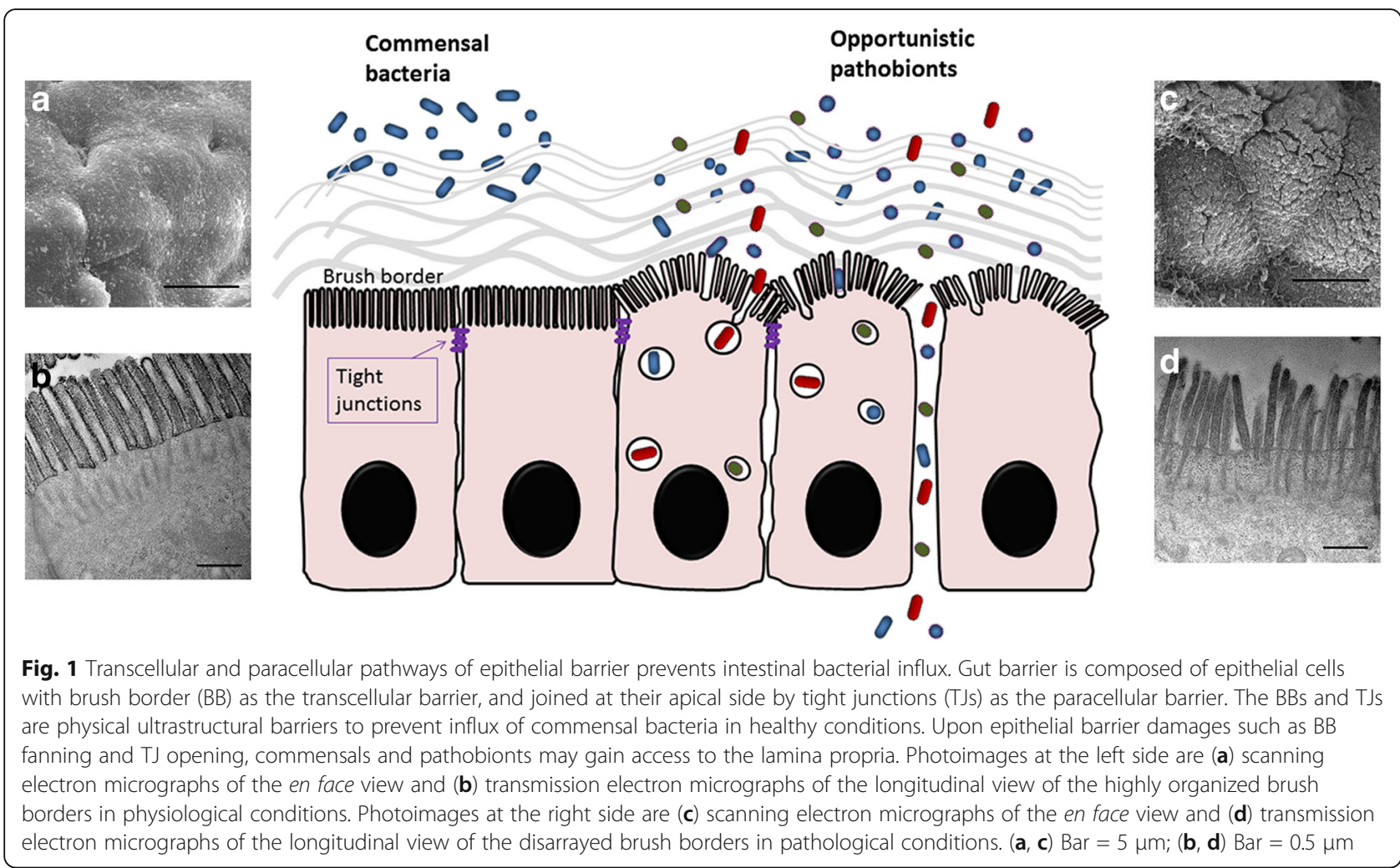

"common ground hypothesis" was proposed to indicate the key roles of microbiota dysbiosis associated with a leaky gut in the pathogenesis of chronic polygenic diseases [9, 168, 169] (Fig. 2). The hypothesis, which still needs to be rigorously examined, first suggests that endogenous and exogenous factors which cause gut barrier impairment and low grade immune activation could impose selective pressure on the intestinal microbiota. The subclinical mucosal abnormalities that developed in individuals with genetic predisposition then favor the growth of opportunistic microbes with virulence emergence. The opportunistic microbes then aggravate the morphologic and functional changes with pathological consequences, and result in chronic inflammation and clinical symptoms in the host (Fig. 2).

Additional evidence also demonstrated that chronic inflammation may shape the gut microbiota and further contribute to dysbiosis [117, 170]. Several lines of evidence have shown that electron acceptors generated as by-products of the inflammatory responses promoted the outgrowth of facultative anaerobes, such as Enterobacteriaceae [171, 172]. Indeed, the mucosa-associated bacteria have higher oxygen tolerance and catalase expression relative to the fecal dominant species [173], which could be an advantage for microbial competition in the gut ecosystem. Alternatively, proinflammatory cytokines (e.g. IFN $\gamma$ and TNF $\alpha$ ) $[24,67,164]$ and opportunistic pathobionts (e.g. AIEC and ETBF) [102, 103, 174] were shown to disrupt epithelial integrity through both transcellular and paracellular pathways. Furthermore, chronic inflammation with high oxidative stress (such as superoxide and nitric oxide) caused epithelial deathdependent barrier loss, which may lead to a vicious cycle of aggravating barrier dysfunction and immune hyperactivation $[175,176]$.

Based on the current knowledge in intestinal barrier regulation (see review papers $[67,177]$ ), we have reconstructed a more detailed hypothesis in attempt to explain the early interaction between epithelial barriers and microbial conversion. In accordance to the "common ground hypothesis", we speculated that an initial epithelial barrier dysfunction manifested by a low amount of passive bacterial internalization for enrichment of specific mucosa-associated bacteria was the first event causing an altered microbial community (Fig. 2). The internalized commensal bacteria inside epithelial cells with aerotolerance may acquire virulence factors to ensure survival, immune evasion, and anchoring advantage. The epithelia-associated driving of opportunistic commensals to pathobionts could be a point of no return leading to pathological consequences to the host. Bacterial internalization may also disturb the epithelial cytoskeletal contour and destabilize junctional structures, resulting in the passage of non-specific bacterial strains. The combination of host barrier defects and bacterial invasiveness may evoke a massive amount of 


\section{Common ground hypothesis}

Exogenous factors (unhealthy diets or contaminants) and endogenous factors (inflammatory or metabolic stress)

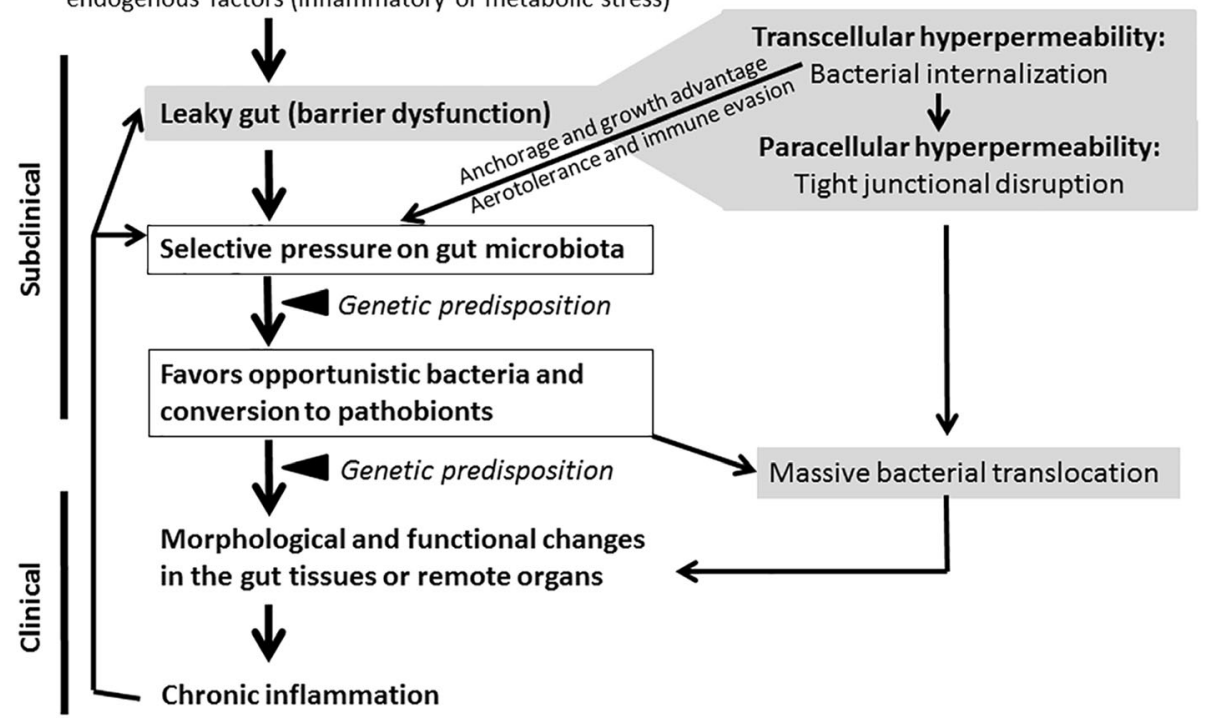

Fig. 2 Proposed schema of early pathophysiological changes in epithelial barrier defects and bacterial invasiveness, which causes microbiota dysbiosis and chronic inflammation. The proposed common ground hypothesis depicting the early abnormality of leaky gut that drives microbiota dysbiosis would lead to chronic inflammation. The hypothesis is that endogenous and exogenous factors that trigger gut barrier impairment and low grade immune activation could impose selective pressure on the intestinal microbiota. The subclinical mucosal abnormalities which developed in individuals with genetic predisposition then favor the growth of opportunistic microbes for conversion to pathobionts. The pathobionts subsequently aggravate morphologic and functional changes in gut tissues and remote organs with pathological consequences, and result in chronic inflammation and clinical symptoms. Further postulation with a detailed focus on the gut barriers are added here. We speculate that the initial epithelial barrier dysfunction manifested by transcellular hyperpermeability and passive bacterial internalization may instigate a selection pressure on microbiota (such as positive inforcement by anchorage and growth advantage, and negative impediment by aerotolerance and immune evasion), leading to the emergence of invasive virulent pathobionts. The selection pressure and mucosal pathobionts may cause a shift in the fecal microbial community. On the host's side, bacterial internalization may also cause epithelial cytoskeletal disorganization and paracellular TJ destruction. The combination of broken epithelial barrier and invasive pathobionts results in a massive amount of bacterial translocation, which leads to clinical features of morphological damage and chronic inflammation. Additional evidence also showed that chronic inflammation may impact on the gut microbiota and cause epithelial death-dependent barrier loss, which eventually leads to vicious cycles of uncontrollable colitis

bacterial translocation and immune hyperactivation in gut mucosa. The immune hyperactivation could impact on the microbiota and cause a further shift to a disease-promoting microbial composition in individuals with genetic predisposition, which eventually leads to chronic inflammation and malignant transformation (Fig. 2).

To date, our understanding of the role of gut microbiota in human health and disease has been fraught with challenges, partly due to the inability to elucidate this complex host-microbe interaction simply based on patient studies. Irrespective of the orders of host or microbial factors involved in disease progression, the co-existence of microbiota dysbiosis and barrier dysfunction (with reciprocal aggravation) appears to be a common instigator in chronic inflammation. Overall, experimental models evaluting subclinical pathophysiological abnormalities (i.e. microbiota dysbiosis and leaky gut) based on the "common ground hypothesis" may serve as a roadmap to decipher the cause-and-effect relationship of disease mechanisms.

\section{Unanswered questions and future directions}

Despite a consensus exists for the presence of microbiota dysbiosis and barrier disruption, the order of the microbial and host factors in disease pathogenesis has not been established in chronic gut inflammation and colitis-associated CRC. Moreover, mucosa-associated pathobionts have been assumed to derive from unharmful gut commensals, yet without direct evidence. One of the proposed triggers for emergence of pathogenic commensals was the need for adaptation to oxidative stress $[178,179]$. Other factors, such as mucosal enrichment and selective pressure, on pathobiont conversion remain to be tested. In addition, the virulence profiles to indicate the conversion of commensal to opportunistic 
pathobionts still need to be determined. Alternatively, whether virulence factors found in opportunistic bacteria (mostly to confer microbial growth advantage) necessarily indicate pathogenic outcome in the hosts or only to those with genetic deficiency warrant further studies.

Furthermore, the majority of microbiome studies so far have focused on bacterial census, and the roles of virus and fungi are less well understood. Since bacteriophages are transferrable and are abundant in the human gut, their roles in modulating the bacterial ecosystems and conferring opportunistic virulence warrant thorough investigation [180, 181]. In addition, bacterial influx due to transcellular and paracellular hyperpermeability in intestinal epithelia was observed in IBD and CRC patients, yet the relative timing of each pathway remains unclear. Timeline studies in experimental models may answer this question, and will provide insights to the differential regulation of distinct transepithelial routes and their relationships to the shaping of gut microbiota.

Fecal microbiota transplantation (FMT) is now standard of care for recurrent Clostridium difficile infection, and emerging evidence also supports the use of FMT to treat IBD [182, 183]. A recent randomized double-blinded controlled trial had shown that FMT induced remission in patients with active UC, which was associated with increased microbial richness without adverse events following transplantation [184, 185]. Some studies reported worsening GI symptoms after FMT in IBD patients by lower GI delivery or in Clostridium infection[186], which may be due to variable donor microbial factors. The possible use of restoration of gut barrier as an indicator of colonization of a healthy microbiota following FMT warrant further studies.

\section{Conclusions}

Research for correction of abnormal microbe-host interaction by sealing the broken barrier and improvement of epithelial integrity is currently in progress to supplement anti-inflammatory and immunotherapies for IBD patients [187-189]. Moreover, novel microbe-focused intervention such as bacterial engineering, next-generation probiotics, microbe-specific bactericidal antibiotics, and fecal microbiota transplantation as a monotherapy or add-on therapy will be promising for IBD treatment [190, 191]. Based on the "common ground hypothesis", targeting the dysbiotic bacteria and intestinal barriers may be used as treatment for not only IBD but also extraintestinal inflammatory disorders and colitis-associated cancers. In addition, the use of microbial signatures in addition to genetic traits as diagnostic biomarkers to predict the prognosis and development of diseases have shown positive results in clinical studies and could be used for personalized medicine in the future [192, 193]. Lastly, diet and prebiotics to affect microbe-microbe and microbe-host interaction would be another valuable approach beyond the known nutritive functions to restore intestinal homeostasis and barrier integrity [194]. In conclusion, the understanding of the core interplay between gut microbiota and host barriers at the early subclinical phase will shed light to novel therapeutic approaches to chronic inflammatory disorders and cancers.

\section{Abbreviations}

AIEC: adherent-invasive Escherichia coli; BB: brush border; CD: Crohn's disease; CEACAM: carcinoemcryonic antigen adhesion molecule;

COX: cyclooxygenase; CRC: colorectal carcinoma; DSS: dextran sulfate sodium; ETBF: enterotoxigenic Bacteroides fragilis; FMT: fecal microbiota transplantation; IBD: inflammatory bowel disease; MLCK: myosin light chain kinase; NOD: nucleotide-binding oligomerization domain; TJ: tight junction; TLR: toll-like receptor; UC: ulcerative colitis

\section{Acknowledgements}

We thank the staff of the imaging core at the First Core Labs and the animal center in National Taiwan University College of Medicine, for technical assistance.

\section{Funding}

Ministry of Science and Technology (MoST 107-2320-B-002-041-MY3), and National Health Research Institute, Taiwan (NHRI-EX105-10520BI,

NHRI-EX106-10520BI, NHRI-EX107-10520BI)

\section{Availability of data and materials \\ NA}

Authors' contributions

Guarantor of integrity of entire manuscript, LCY; manuscript drafting and revision for important intellectual content, literature research, and manuscript final version approval: LCY

Ethics approval and consent to participate NA

Consent for publication

NA

Competing interests

I declare that there is no competing interest.

\section{Publisher's Note}

Springer Nature remains neutral with regard to jurisdictional claims in published maps and institutional affiliations.

Received: 21 August 2018 Accepted: 29 October 2018

Published online: 09 November 2018

\section{References}

1. Sender R, Fuchs S, Milo R. Are We Really Vastly Outnumbered? Revisiting the Ratio of Bacterial to Host Cells in Humans. Cell. 2016;164(3):337-40.

2. Nakamoto N, Schnabl B. Does the Intestinal Microbiota Explain Differences in the Epidemiology of Liver Disease between East and West? Inflamm Intest Dis. 2016;1(1):3-8.

3. Turnbaugh PJ, Ley RE, Hamady M, Fraser-Liggett CM, Knight R, Gordon Jl. The human microbiome project. Nature. 2007;449(7164):804-10.

4. Yu LC, Wang JT, Wei SC, Ni YH. Host-microbial interactions and regulation of intestinal epithelial barrier function: From physiology to pathology. World J Gastrointest Pathophysiol. 2012;3(1):27-43.

5. Balzan S, de Almeida Quadros C, de Cleva R, Zilberstein B, Cecconello I. Bacterial translocation: overview of mechanisms and clinical impact. J GastroenterolHepatol. 2007;22(4):464-71.

6. Leaphart $\mathrm{CL}$, Tepas JJ, III: The gut is a motor of organ system dysfunction. Surgery 2007, 141(5):563-569.

7. Ni J, Wu GD, Albenberg L, Tomov VT. Gut microbiota and IBD: causation or correlation? Nat Rev Gastroenterol Hepatol. 2017;14(10):573-84. 
8. Bernstein CN, Forbes JD. Gut Microbiome in Inflammatory Bowel Disease and Other Chronic Immune-Mediated Inflammatory Diseases. Inflammatory Intestinal Diseases. 2017;2:116-23.

9. Lynch SV, Pedersen O. The Human Intestinal Microbiome in Health and Disease. N Engl J Med. 2016;375(24):2369-79.

10. Slyepchenko A, Maes M, Machado-Veira R, Anderson G, Solmi M, Sanz Y, Berk M, Kohler CA, Carvalho AF. Intestinal dysbiosis, gut hyperpermeability and bacterial translocation: missing links between depression, obesity and type 2 diabetes? Curr Pharm Des. 2016.

11. Rogler G, Rosano G. The heart and the gut. Eur Heart J. 2014;35(7):426-30

12. Kohler CA, Maes M, Slyepchenko A, Berk M, Solmi M, Lanctot KL, Carvalho AF. The Gut-Brain Axis, Including the Microbiome, Leaky Gut and Bacterial Translocation: Mechanisms and Pathophysiological Role in Alzheimer's Disease. Curr Pharm Des. 2016;22(40):6152-66.

13. Chua HH, Chou HC, Tung YL, Chiang BL, Liao CC, Liu HH, Ni YH. Intestinal Dysbiosis Featuring Abundance of Ruminococcus gnavus Associates With Allergic Diseases in Infants. Gastroenterology. 2018; 154(1):154-67.

14. Prorok-Hamon M, Friswell MK, Alswied A, Roberts CL, Song F, Flanagan PK, Knight P, Codling C, Marchesi JR, Winstanley C, et al. Colonic mucosaassociated diffusely adherent afaC+ Escherichia coli expressing IpfA and pks are increased in inflammatory bowel disease and colon cancer. Gut. 2014;63(5):761-70.

15. Martin HM, Campbell BJ, Hart CA, Mpofu C, Nayar M, Singh R, Englyst H, Williams HF, Rhodes JM. Enhanced Escherichia coli adherence and invasion in Crohn's disease and colon cancer. Gastroenterology. 2004;127(1):80-93.

16. Kahrstrom CT. Bacterial pathogenesis: E. coli claims the driving seat for cancer. Nature Rev Microbiol. 2012;10(10):670.

17. Chassaing B, Gewirtz AT. Pathobiont hypnotises enterocytes to promote tumour development. Gut. 2014;63(12):1837-8.

18. Girbovan A, Sur G, Samasca G, Lupan I. Dysbiosis a risk factor for celiac disease. Med Microbiol Immunol. 2017;206(2):83-91.

19. Cinova J, De Palma G, Stepankova R, Kofronova O, Kverka M, Sanz Y, Tuckova L. Role of intestinal bacteria in gliadin-induced changes in intestinal mucosa: study in germ-free rats. PLoS One. 2011;6(1):e16169.

20. Silva MA, Jury J, Sanz Y, Wiepjes M, Huang X, Murray JA, David CS, Fasano A, Verdu EF. Increased bacterial translocation in gluten-sensitive mice is independent of small intestinal paracellular permeability defect. Dig Dis Sci. 2012;57(1):38-47.

21. Ludvigsson JF, Olen O, Bell M, Ekbom A, Montgomery SM. Coeliac disease and risk of sepsis. Gut. 2008;57(8):1074-80.

22. Caminero A, Galipeau HJ, McCarville JL, Johnston CW, Bernier SP, Russell AK, Jury J, Herran AR, Casqueiro J, Tye-Din JA, et al. Duodenal Bacteria From Patients With Celiac Disease and Healthy Subjects Distinctly Affect Gluten Breakdown and Immunogenicity. Gastroenterology. 2016;151(4):670-83.

23. Wu CC, Lu YZ, Wu LL, Yu LCH. Role of myosin light chain kinase in intestinal epithelial barrier defects in a rat model of bowel obstruction. BMC Gastroenterology. 2010;10:39-50.

24. Wu LL, Peng WH, Kuo WT, Huang CY, Ni YH, Lu KS, Turner JR, Yu LC. Commensal Bacterial Endocytosis in Epithelial Cells Is Dependent on Myosin Light Chain Kinase-Activated Brush Border Fanning by Interferon-gamma. Am J Pathol. 2014;184(8):2260-74.

25. Tian F, Gao X, Zhang L, Wang X, Wan X, Jiang T, Wu C, Bi J, Lei Q. Effects of $n-3$ PUFAs on Intestinal Mucosa Innate Immunity and Intestinal Microbiota in Mice after Hemorrhagic Shock Resuscitation. Nutrients. 2016;8(10).

26. Yu LC, Shih YA, Wu LL, Lin YD, Kuo WT, Peng WH, Lu KS, Wei SC, Turner JR, $\mathrm{Ni}$ YH. Enteric dysbiosis promotes antibiotic-resistant bacterial infection: systemic dissemination of resistant and commensal bacteria through epithelial transcytosis. Am J Physiol Gastrointest Liver Physiol. 2014;307(8):G824-35.

27. Ubeda C, Taur Y, Jenq RR, Equinda MJ, Son T, Samstein M, Viale A, Socci ND, van den Brink MR, Kamboj M, et al. Vancomycin-resistant Enterococcus domination of intestinal microbiota is enabled by antibiotic treatment in mice and precedes bloodstream invasion in humans. J Clin Invest. 2010;120(12):4332-41.

28. Beatty JK, Akierman SV, Motta JP, Muise S, Workentine ML, Harrison JJ, Bhargava A, Beck PL, Rioux KP, McKnight GW, et al. Giardia duodenalis induces pathogenic dysbiosis of human intestinal microbiota biofilms. Int J Parasitol. 2017;47(6):311-26.
29. Barash NR, Maloney JG, Singer SM, Dawson SC: Giardia Alters Commensal Microbial Diversity throughout the Murine Gut. Infect Immun. 2017:85(6): e00948-16.

30. Brackmann S, Andersen SN, Aamodt G, Langmark F, Clausen OP, Aadland E, Fausa O, Rydning A, Vatn MH. Relationship between clinical parameters and the colitis-colorectal cancer interval in a cohort of patients with colorectal cancer in inflammatory bowel disease. Scand J Gastroenterol. 2009;44(1):46-55.

31. Browning BL, Huebner C, Petermann I, Gearry RB, Barclay ML, Shelling AN, Ferguson LR. Has toll-like receptor 4 been prematurely dismissed as an inflammatory bowel disease gene? Association study combined with metaanalysis shows strong evidence for association. Am J Gastroenterol. 2007;102(11):2504-12.

32. De Jager PL, Franchimont D, Waliszewska A, Bitton A, Cohen A, Langelier D, Belaiche J, Vermeire S, Farwell L, Goris A, et al. The role of the Toll receptor pathway in susceptibility to inflammatory bowel diseases. Genes Immun. 2007;8(5):387-97.

33. Brand S, Staudinger T, Schnitzler F, Pfennig S, Hofbauer K, Dambacher J, Seiderer J, Tillack C, Konrad A, Crispin A, et al. The role of Toll-like receptor 4 Asp299Gly and Thr399lle polymorphisms and CARD15/NOD2 mutations in the susceptibility and phenotype of Crohn's disease. Inflamm Bowel Dis. 2005; 11(7):645-52.

34. Lakatos PL, Hitre E, Szalay F, Zinober K, Fuszek P, Lakatos L, Fischer S, Osztovits J, Gemela O, Veres G, et al. Common NOD2/CARD15 variants are not associated with susceptibility or the clinicopathologic characteristics of sporadic colorectal cancer in Hungarian patients. BMC Cancer. 2007;7:54.

35. Franchimont D, Vermeire S, El HH, Pierik M, Van SK, Gustot T, Quertinmont E, Abramowicz M, Van GA, Deviere J, et al. Deficient host-bacteria interactions in inflammatory bowel disease? The toll-like receptor (TLR)-4 Asp299gly polymorphism is associated with Crohn's disease and ulcerative colitis. Gut. 2004:53(7):987-92.

36. Slattery ML, Herrick JS, Bondurant KL, Wolff RK. Toll-like receptor genes and their association with colon and rectal cancer development and prognosis. Int J Cancer. 2012;130(12):2974-80.

37. Semlali A, Reddy Parine N, Arafah M, Mansour L, Azzi A, Al Shahrani O, Al Amri A, Shaik JP, Aljebreen AM, Alharbi O, et al. Expression and Polymorphism of Toll-Like Receptor 4 and Effect on NF-kappaB Mediated Inflammation in Colon Cancer Patients. PLoS One. 2016;11(1):e0146333.

38. Grimm WA, Messer JS, Murphy SF, Nero T, Lodolce JP, Weber CR, Logsdon MF, Bartulis S, Sylvester BE, Springer A, et al. The Thr300Ala variant in ATG16L1 is associated with improved survival in human colorectal cancer and enhanced production of type I interferon. Gut. 2016;65(3):456-64.

39. Kuo WT, Lee TC, Yang HY, Chen CY, Au YC, Lu YZ, Wu LL, Wei SC, Ni YH, Lin $\mathrm{BR}$, et al. LPS receptor subunits have antagonistic roles in epithelial apoptosis and colonic carcinogenesis. Cell Death Differ. 2015;22(10):1590-604.

40. Rakoff-Nahoum S, Medzhitov R. Role of toll-like receptors in tissue repair and tumorigenesis. Biochemistry (Mosc). 2008;73(5):555-61.

41. Kuo WT, Lee TC, Yu LC. Eritoran Suppresses Colon Cancer by Altering a Functional Balance in Toll-like Receptors That Bind Lipopolysaccharide. Cancer Res. 2016;76(16):4684-95.

42. Fukata M, Hernandez Y, Conduah D, Cohen J, Chen A, Breglio K, Goo T, Hsu D, Xu R, Abreu MT. Innate immune signaling by Toll-like receptor-4 (TLR4) shapes the inflammatory microenvironment in colitis-associated tumors. Inflamm Bowel Dis. 2009;15(7):997-1006.

43. Yu LC, Wei SC, Ni YN. Interplay between the gut microbiota and epithelial innate signaling in colitis-associated colon carcinogenesis. Cancer Res Frontiers. 2017:3(1):1-28.

44. Nagalingam NA, Kao JY, Young VB. Microbial ecology of the murine gut associated with the development of dextran sodium sulfate-induced colitis. Inflamm Bowel Dis. 2011;17(4):917-26.

45. Samanta AK, Torok VA, Percy NJ, Abimosleh SM, Howarth GS. Microbial fingerprinting detects unique bacterial communities in the faecal microbiota of rats with experimentally-induced colitis. J Microbiol. 2012;50(2):218-25.

46. Brinkman BM, Becker A, Ayiseh RB, Hildebrand F, Raes J, Huys G, Vandenabeele P. Gut microbiota affects sensitivity to acute DSS-induced colitis independently of host genotype. Inflamm Bowel Dis. 2013;19(12): 2560-7.

47. Kolho KL, Korpela K, Jaakkola T, Pichai MV, Zoetendal EG, Salonen A, de Vos WM. Fecal Microbiota in Pediatric Inflammatory Bowel Disease and Its Relation to Inflammation. Am J Gastroenterol. 2015;110(6):921-30. 
48. Qin J, Li R, Raes J, Arumugam M, Burgdorf KS, Manichanh C, Nielsen T, Pons $\mathrm{N}$, Levenez F, Yamada $\mathrm{T}$, et al. A human gut microbial gene catalogue established by metagenomic sequencing. Nature. 2010;464(7285):59-65.

49. Manichanh C, Rigottier-Gois L, Bonnaud E, Gloux K, Pelletier E, Frangeul L, Nalin R, Jarrin C, Chardon P, Marteau P, et al. Reduced diversity of faecal microbiota in Crohn's disease revealed by a metagenomic approach. Gut. 2006;55(2):205-11.

50. Miyoshi J, Chang EB. The gut microbiota and inflammatory bowel diseases. Transl Res. 2017;179:38-48.

51. Kostic AD, Xavier RJ, Gevers D. The microbiome in inflammatory bowel disease: current status and the future ahead. Gastroenterology. 2014;146(6):1489-99.

52. Ley RE, Turnbaugh PJ, Klein S, Gordon Jl. Microbial ecology: human gut microbes associated with obesity. Nature. 2006;444(7122):1022-3.

53. Eckburg PB, Bik EM, Bernstein CN, Purdom E, Dethlefsen L, Sargent M, Gill $\mathrm{SR}$, Nelson KE, Relman DA. Diversity of the human intestinal microbial flora. Science. 2005;308(5728):1635-8.

54. Seksik P, Rigottier-Gois L, Gramet G, Sutren M, Pochart P, Marteau P, Jian R, Dore J. Alterations of the dominant faecal bacterial groups in patients with Crohn's disease of the colon. Gut. 2003;52(2):237-42.

55. Chen L, Wang W, Zhou R, Ng SC, Li J, Huang M, Zhou F, Wang X, Shen B, AK M, et al. Characteristics of fecal and mucosa-associated microbiota in Chinese patients with inflammatory bowel disease. Medicine (Baltimore). 2014;93(8):e51

56. Zhou Y, Chen H, He H, Du Y, Hu J, Li Y, Li Y, Zhou Y, Wang H, Chen Y, et al. Increased Enterococcus faecalis infection is associated with clinically active Crohn disease. Medicine (Baltimore). 2016;95(39):e5019.

57. Prosberg M, Bendtsen F, Vind I, Petersen AM, Gluud LL. The association between the gut microbiota and the inflammatory bowel disease activity: a systematic review and meta-analysis. Scand J Gastroenterol. 2016:1-9.

58. Maukonen J, Kolho KL, Paasela M, Honkanen J, Klemetti P, Vaarala O, Saarela M. Altered Fecal Microbiota in Paediatric Inflammatory Bowel Disease. J Crohns Colitis. 2015;9(12):1088-95.

59. Sokol H, Pigneur B, Watterlot L, Lakhdari O, Bermudez-Humaran LG, Gratadoux JJ, Blugeon S, Bridonneau C, Furet JP, Corthier G, et al. Faecalibacterium prausnitzii is an anti-inflammatory commensal bacterium identified by gut microbiota analysis of Crohn disease patients. Proc Nat Acad Sci U S A. 2008;105(43):16731-6.

60. Walker AW, Sanderson JD, Churcher C, Parkes GC, Hudspith BN, Rayment N, Brostoff J, Parkhill J, Dougan G, Petrovska L. High-throughput clone library analysis of the mucosa-associated microbiota reveals dysbiosis and differences between inflamed and non-inflamed regions of the intestine in inflammatory bowel disease. BMC Microbiol. 2011;11:7.

61. Hansen R, Russell RK, Reiff $C$, Louis P, Mclntosh F, Berry SH, Mukhopadhya I, Bisset WM, Barclay AR, Bishop J, et al. Microbiota of de-novo pediatric IBD: increased Faecalibacterium prausnitzii and reduced bacterial diversity in Crohn's but not in ulcerative colitis. Am J Gastroenterol. 2012;107(12):1913-22.

62. Lepage $P$, Hasler R, Spehlmann ME, Rehman A, Zvirbliene A, Begun A, Ott S, Kupcinskas L, Dore J, Raedler A, et al. Twin study indicates loss of interaction between microbiota and mucosa of patients with ulcerative colitis. Gastroenterology. 2011;141(1):227-36.

63. Pascal V, Pozuelo M, Borruel N, Casellas F, Campos D, Santiago A, Martinez X, Varela E, Sarrabayrouse G, Machiels K, et al. A microbial signature for Crohn's disease. Gut. 2017;66(5):813-22.

64. Swidsinski A, Weber J, Loening-Baucke V, Hale LP, Lochs H. Spatial organization and composition of the mucosal flora in patients with inflammatory bowel disease. J Clin Microbiol. 2005;43(7):3380-9.

65. Kleessen B, Kroesen AJ, Buhr HJ, Blaut M. Mucosal and invading bacteria in patients with inflammatory bowel disease compared with controls. Scand J Gastroenterol. 2002;37(9):1034-41.

66. Gevers D, Kugathasan S, Denson LA, Vazquez-Baeza Y, Van Treuren W, Ren $B$, Schwager E, Knights D, Song SJ, Yassour M, et al. The treatment-naive microbiome in new-onset Crohn's disease. Cell Host \& Microbe. 2014;15(3):382-92.

67. Yu LC. Commensal bacterial internalization by epithelial cells: An alternative portal for gut leakiness. Tissue Barriers. 2015;3(3):e1008895.

68. Johansson ME, Sjovall H, Hansson GC. The gastrointestinal mucus system in health and disease. Nat Rev Gastroenterol Hepatol. 2013;10(6):352-61.

69. Johansson ME, Gustafsson JK, Holmen-Larsson J, Jabbar KS, Xia L, Xu $H$, Ghishan FK, Carvalho FA, Gewirtz AT, Sjovall H, et al. Bacteria penetrate the normally impenetrable inner colon mucus layer in both murine colitis models and patients with ulcerative colitis. Gut. 2014;63(2):281-91.

70. Mylonaki M, Rayment NB, Rampton DS, Hudspith BN, Brostoff J. Molecular characterization of rectal mucosa-associated bacterial flora in inflammatory bowel disease. Inflamm Bowel Dis. 2005;11(5):481-7.

71. Motta JP, Allain T, Green-Harrison LE, Groves RA, Feener T, Ramay H, Beck PL, Lewis IA, Wallace JL, Buret AG. Iron Sequestration in Microbiota Biofilms As A Novel Strategy for Treating Inflammatory Bowel Disease. Inflamm Bowel Dis. 2018;24(7):1493-502.

72. Darfeuille-Michaud A, Boudeau J, Bulois P, Neut C, Glasser AL, Barnich N, Bringer MA, Swidsinski A, Beaugerie L, Colombel JF. High prevalence of adherent-invasive Escherichia coli associated with ileal mucosa in Crohn's disease. Gastroenterology. 2004;127(2):412-21.

73. Martinez-Medina M, Aldeguer X, Lopez-Siles M, Gonzalez-Huix F, Lopez-Oliu C, Dahbi G, Blanco JE, Blanco J, Garcia-Gil LJ, Darfeuille-Michaud A. Molecular diversity of Escherichia coli in the human gut: new ecological evidence supporting the role of adherent-invasive E. coli (AIEC) in Crohn's disease. Inflamm Bowel Dis. 2009;15(6):872-82.

74. Baumgart M, Dogan B, Rishniw M, Weitzman G, Bosworth B, Yantiss R, Orsi $\mathrm{RH}$, Wiedmann $\mathrm{M}, \mathrm{McD}$ onough $\mathrm{P}, \mathrm{Kim} \mathrm{SG}$, et al. Culture independent analysis of ileal mucosa reveals a selective increase in invasive Escherichia coli of novel phylogeny relative to depletion of Clostridiales in Crohn's disease involving the ileum. ISME J. 2007;1(5):403-18.

75. Eaves-Pyles T, Allen CA, Taormina J, Swidsinski A, Tutt CB, Jezek GE, Islas-Islas $M$, Torres AG. Escherichia coli isolated from a Crohn's disease patient adheres, invades, and induces inflammatory responses in polarized intestinal epithelial cells. Int J Med Microbiol. 2008;298(5-6):397-409.

76. Sears CL, Islam S, Saha A, Arjumand M, Alam NH, Faruque AS, Salam MA, Shin J, Hecht D, Weintraub A, et al. Association of enterotoxigenic Bacteroides fragilis infection with inflammatory diarrhea. Clin Infect Dis. 2008;47(6):797-803.

77. Viljoen KS, Dakshinamurthy A, Goldberg P, Blackburn JM. Quantitative profiling of colorectal cancer-associated bacteria reveals associations between fusobacterium spp., enterotoxigenic Bacteroides fragilis (ETBF) and clinicopathological features of colorectal cancer. PLoS One 2015;10(3):e0119462.

78. Boleij A, Hechenbleikner EM, Goodwin AC, Badani R, Stein EM, Lazarev MG, Ellis $B$, Carroll KC, Albesiano E, Wick EC, et al. The Bacteroides fragilis toxin gene is prevalent in the colon mucosa of colorectal cancer patients. Clin Infect Dis. 2015;60(2):208-15.

79. Golinska E, Tomusiak A, Gosiewski T, Wiecek G, Machul A, Mikolajczyk D, Bulanda M, Heczko PB, Strus M. Virulence factors of Enterococcus strains isolated from patients with inflammatory bowel disease. World J Gastroenterol. 2013;19(23):3562-72.

80. Hudcovic T, Stepankova R, Cebra J, Tlaskalova-Hogenova H. The role of microflora in the development of intestinal inflammation: acute and chronic colitis induced by dextran sulfate in germ-free and conventionally reared immunocompetent and immunodeficient mice. Folia Microbiol (Praha). 2001;46(6):565-72.

81. Kim SC, Tonkonogy SL, Albright CA, Tsang J, Balish EJ, Braun J, Huycke MM, Sartor RB. Variable phenotypes of enterocolitis in interleukin 10-deficient mice monoassociated with two different commensal bacteria. Gastroenterology. 2005;128(4):891-906.

82. Llewellyn SR, Britton GJ, Contijoch EJ, Vennaro OH, Mortha A, Colombel JF, Grinspan A, Clemente JC, Merad M, Faith JJ. Interactions between diet and the intestinal microbiota alter intestinal permeability and colitis severity in mice. Gastroenterology. 2017.

83. Hernandez-Chirlaque C, Aranda CJ, Ocon B, Capitan-Canadas F, OrtegaGonzalez M, Carrero JJ, Suarez MD, Zarzuelo A, Sanchez de Medina F, Martinez-Augustin O. Germ-free and Antibiotic-treated Mice are Highly Susceptible to Epithelial Injury in DSS Colitis. J Crohns Colitis. 2016;10(11):1324-35

84. Contractor NV, Bassiri H, Reya T, Park AY, Baumgart DC, Wasik MA, Emerson SG, Carding SR. Lymphoid hyperplasia, autoimmunity, and compromised intestinal intraepithelial lymphocyte development in colitis-free gnotobiotic IL-2-deficient mice. J Immunol. 1998;160(1):385-94.

85. Chung H, Pamp SJ, Hill JA, Surana NK, Edelman SM, Troy EB, Reading NC, Villablanca EJ, Wang S, Mora JR, et al. Gut immune maturation depends on colonization with a host-specific microbiota. Cell. 2012; 149(7):1578-93. 
86. Vannucci L, Stepankova R, Kozakova H, Fiserova A, Rossmann P, TlaskalovaHogenova $\mathrm{H}$. Colorectal carcinogenesis in germ-free and conventionally reared rats: different intestinal environments affect the systemic immunity. Int J Oncol. 2008;32(3):609-17.

87. Rhee KJ, Sethupathi P, Driks A, Lanning DK, Knight KL. Role of commensal bacteria in development of gut-associated lymphoid tissues and preimmune antibody repertoire. J Immunol. 2004;172(2):1118-24.

88. Couturier-Maillard A, Secher T, Rehman A, Normand S, De Arcangelis A, Haesler R, Huot L, Grandjean T, Bressenot A, Delanoye-Crespin A et al: NOD2-mediated dysbiosis predisposes mice to transmissible colitis and colorectal cancer. J Clin Invest 2013, 123(2):700-711.

89. Hu B, Elinav E, Huber S, Strowig T, Hao L, Hafemann A, Jin C, Wunderlich C, Wunderlich T, Eisenbarth SC, et al. Microbiota-induced activation of epithelial IL-6 signaling links inflammasome-driven inflammation with transmissible cancer. Proc Natl Acad Sci U S A. 2013;110(24):9862-7.

90. Carvalho FA, Barnich N, Sivignon A, Darcha C, Chan CH, Stanners CP, Darfeuille-Michaud A. Crohn's disease adherent-invasive Escherichia coli colonize and induce strong gut inflammation in transgenic mice expressing human CEACAM. J Exp Med. 2009;206(10):2179-89.

91. Boudeau J, Barnich N, Darfeuille-Michaud A. Type 1 pili-mediated adherence of Escherichia coli strain LF82 isolated from Crohn's disease is involved in bacterial invasion of intestinal epithelial cells. Mol Microbiol. 2001;39(5):1272-84.

92. Glasser AL, Boudeau J, Barnich N, Perruchot MH, Colombel JF, DarfeuilleMichaud A. Adherent invasive Escherichia coli strains from patients with Crohn's disease survive and replicate within macrophages without inducing host cell death. Infect Immun. 2001;69(9):5529-37.

93. Raisch J, Rolhion N, Dubois A, Darfeuille-Michaud A, Bringer MA. Intracellular colon cancer-associated Escherichia coli promote protumoral activities of human macrophages by inducing sustained COX-2 expression. Lab Invest. 2015;95(3):296-307.

94. Lu C, Chen J, Xu HG, Zhou X, He Q, Li YL, Jiang G, Shan Y, Xue B, Zhao RX, et al. MIR106B and MIR93 prevent removal of bacteria from epithelial cells by disrupting ATG16L1-mediated autophagy. Gastroenterology. 2014;146(1):188-99.

95. Nguyen HT, Dalmasso G, Muller S, Carriere J, Seibold F, Darfeuille-Michaud A. Crohn's disease-associated adherent invasive Escherichia coli modulate levels of microRNAs in intestinal epithelial cells to reduce autophagy. Gastroenterology. 2014;146(2):508-19.

96. Sadaghian Sadabad M, Regeling A, de Goffau MC, Blokzijl T, Weersma RK, Penders J, Faber KN, Harmsen HJ, Dijkstra G: The ATG16L1-T300A allele impairs clearance of pathosymbionts in the inflamed ileal mucosa of Crohn's disease patients. Gut 2015, 64(10):1546-1552.

97. Kim SC, Tonkonogy SL, Karrasch T, Jobin C, Sartor RB. Dual-association of gnotobiotic IL-10-/- mice with 2 nonpathogenic commensal bacteria induces aggressive pancolitis. Inflamm Bowel Dis. 2007;13(12):1457-66.

98. Karrasch T, Kim JS, Muhlbauer M, Magness ST, Jobin C. Gnotobiotic IL-10-/-;NF-kappa B(EGFP) mice reveal the critical role of TLR/NF-kappa B signaling in commensal bacteria-induced colitis. J Immunol. 2007;178(10):6522-32.

99. Rhee KJ, Wu S, Wu X, Huso DL, Karim B, Franco AA, Rabizadeh S, Golub JE, Mathews LE, Shin J, et al. Induction of persistent colitis by a human commensal, enterotoxigenic Bacteroides fragilis, in wild-type C57BL/6 mice. Infect Immun. 2009;77(4):1708-18.

100. Rabizadeh S, Rhee KJ, Wu S, Huso D, Gan CM, Golub JE, Wu X, Zhang M, Sears CL. Enterotoxigenic bacteroides fragilis: a potential instigator of colitis. Inflamm Bowel Dis. 2007;13(12):1475-83.

101. Wick EC, Rabizadeh S, Albesiano E, Wu X, Wu S, Chan J, Rhee KJ, Ortega G, Huso DL, Pardoll D, et al. Stat3 activation in murine colitis induced by enterotoxigenic Bacteroides fragilis. Inflamm Bowel Dis. 2014;20(5):821-34.

102. Remacle AG, Shiryaev SA, Strongin AY. Distinct interactions with cellular Ecadherin of the two virulent metalloproteinases encoded by a Bacteroides fragilis pathogenicity island. PLoS One. 2014;9(11):e113896.

103. Hwang S, Gwon SY, Kim MS, Lee S, Rhee KJ. Bacteroides fragilis Toxin Induces IL-8 Secretion in HT29/C1 Cells through Disruption of E-cadherin Junctions. Immune Netw. 2013;13(5):213-7.

104. Setoyama H, Imaoka A, Ishikawa H, Umesaki Y. Prevention of gut inflammation by Bifidobacterium in dextran sulfate-treated gnotobiotic mice associated with Bacteroides strains isolated from ulcerative colitis patients. Microbes and infection / Institut Pasteur. 2003;5(2):115-22.
105. Barnett MP, McNabb WC, Cookson AL, Zhu S, Davy M, Knoch B, Nones K, Hodgkinson AJ, Roy NC. Changes in colon gene expression associated with increased colon inflammation in interleukin-10 gene-deficient mice inoculated with Enterococcus species. BMC Immunol. 2010;11:39.

106. Steck N, Hoffmann M, Sava IG, Kim SC, Hahne H, Tonkonogy SL, Mair K, Krueger D, Pruteanu M, Shanahan F, et al. Enterococcus faecalis metalloprotease compromises epithelial barrier and contributes to intestinal inflammation. Gastroenterology. 2011;141(3):959-71.

107. Ocvirk S, Sava IG, Lengfelder I, Lagkouvardos I, Steck N, Roh JH, Tchaptchet S, Bao Y, Hansen JJ, Huebner J, et al. Surface-Associated Lipoproteins Link Enterococcus faecalis Virulence to Colitogenic Activity in IL-10-Deficient Mice Independent of Their Expression Levels. PLoS Pathog. 2015;11(6):e1004911.

108. Pulusu SSR, Lawrance IC. Dysplasia and colorectal cancer surveillance in inflammatory bowel disease. Expert Rev Gastroenterol Hepatol. 2017;11(8):711-22.

109. Giglia MD, Chu Dl. Familial Colorectal Cancer: Understanding the Alphabet Soup. Clin Colon Rectal Surg. 2016;29(3):185-95.

110. Fumery M, Dulai PS, Gupta S, Prokop LJ, Ramamoorthy S, Sandborn WJ, Singh S. Incidence, Risk Factors, and Outcomes of Colorectal Cancer in Patients With Ulcerative Colitis With Low-Grade Dysplasia: A Systematic Review and Meta-analysis. Clin Gastroenterol Hepatol. 2017;15(5):665-74 e665.

111. Giardiello FM, Krush AJ, Petersen GM, Booker SV, Kerr M, Tong LL, Hamilton SR. Phenotypic variability of familial adenomatous polyposis in 11 unrelated families with identical APC gene mutation. Gastroenterology. 1994;106(6): 1542-7.

112. Laurent S, Franchimont D, Coppens JP, Leunen K, Macken L, Peeters M, Plomteux O, Polus M, Poppe B, Sempoux C, et al. Familial adenomatous polyposis: clinical presentation, detection and surveillance. Acta Gastroenterol Belg. 2011;74(3):415-20.

113. Dejea CM, Fathi P, Craig JM, Boleij A, Taddese R, Geis AL, Wu X, DeStefano Shields CE, Hechenbleikner EM, Huso DL, et al. Patients with familial adenomatous polyposis harbor colonic biofilms containing tumorigenic bacteria. Science. 2018:359(6375):592-7.

114. Gao R, Kong C, Huang L, Li H, Qu X, Liu Z, Lan P, Wang J, Qin H. Mucosaassociated microbiota signature in colorectal cancer. Eur J Clin Microbiol Infect Dis. 2017.

115. Chen W, Liu F, Ling Z, Tong X, Xiang C. Human intestinal lumen and mucosa-associated microbiota in patients with colorectal cancer. PLoS One. 2012;7(6):e39743.

116. Kostic AD, Chun E, Robertson L, Glickman JN, Gallini CA, Michaud M, Clancy $\mathrm{TE}$, Chung DC, Lochhead P, Hold GL, et al. Fusobacterium nucleatum potentiates intestinal tumorigenesis and modulates the tumor-immune microenvironment. Cell host \& microbe. 2013;14(2):207-15.

117. Arthur JC, Perez-Chanona E, Muhlbauer M, Tomkovich S, Uronis JM, Fan TJ, Campbell BJ, Abujamel T, Dogan B, Rogers AB, et al. Intestinal inflammation targets cancer-inducing activity of the microbiota. Science. 2012;338(6103):120-3.

118. Goodwin AC, Destefano Shields CE, Wu S, Huso DL, Wu X, Murray-Stewart TR, Hacker-Prietz A, Rabizadeh S, Woster PM, Sears CL, et al. Polyamine catabolism contributes to enterotoxigenic Bacteroides fragilis-induced colon tumorigenesis. Proc Natl Acad Sci U S A. 2011;108(37):15354-9.

119. Yang $Y$, Weng $W$, Peng J, Hong L, Yang L, Toiyama $Y$, Gao R, Liu M, Yin M, Pan C, et al. Fusobacterium nucleatum Increases Proliferation of Colorectal Cancer Cells and Tumor Development in Mice by Activating Toll-Like Receptor 4 Signaling to Nuclear Factor-kappaB, and Upregulating Expression of MicroRNA-21. Gastroenterology. 2017;152(4):851-66 e824.

120. Bonnet M, Buc E, Sauvanet P, Darcha C, Dubois D, Pereira B, Dechelotte P, Bonnet R, Pezet D, Darfeuille-Michaud A. Colonization of the human gut by $E$. coli and colorectal cancer risk. Clinical cancer research : an official journal of the American Association for Cancer Research. 2014; 20(4):859-67.

121. Yu LC, Wei SC, Ni YH. Impact of Microbiota in Colorectal Carcinogenesis: Lessons from Experimental Models. Intestinal Research. 2018.

122. Wu S, Rhee KJ, Albesiano E, Rabizadeh S, Wu X, Yen HR, Huso DL, Brancati FL, Wick E, McAllister F, et al. A human colonic commensal promotes colon tumorigenesis via activation of T helper type $17 \mathrm{~T}$ cell responses. Nat Med. 2009;15(9):1016-22.

123. Arthur JC, Gharaibeh RZ, Muhlbauer M, Perez-Chanona E, Uronis JM, McCafferty J, Fodor AA, Jobin C. Microbial genomic analysis reveals the 
essential role of inflammation in bacteria-induced colorectal cancer. Nature Commun. 2014:5:4724.

124. Chen GY, Shaw MH, Redondo G, Nunez G. The innate immune receptor Nod1 protects the intestine from inflammation-induced tumorigenesis. Cancer Res. 2008;68(24):10060-7.

125. Normand S, Delanoye-Crespin A, Bressenot A, Huot L, Grandjean T, PeyrinBiroulet L, Lemoine $Y$, Hot D, Chamaillard M. Nod-like receptor pyrin domain-containing protein 6 (NLRP6) controls epithelial self-renewal and colorectal carcinogenesis upon injury. Proc Natl Acad Sci U S A. 2011;108(23):9601-6

126. Chan CH, Cook D, Stanners CP. Increased colon tumor susceptibility in azoxymethane treated CEABAC transgenic mice. Carcinogenesis. 2006;27(9):1909-16.

127. Raisch J, Buc E, Bonnet M, Sauvanet P, Vazeille E, de Vallee A, Dechelotte $P$, Darcha C, Pezet D, Bonnet R, et al. Colon cancer-associated B2 Escherichia coli colonize gut mucosa and promote cell proliferation. World J Gastroenterol. 2014;20(21):6560-72.

128. Tomkovich S, Yang Y, Winglee $K$, Gauthier J, Muhlbauer M, Sun X, Mohamadzadeh M, Liu X, Martin P, Wang GP, et al. Locoregional Effects of Microbiota in a Preclinical Model of Colon Carcinogenesis. Cancer Res. 2017;77(10):2620-32

129. Cougnoux A, Dalmasso G, Martinez R, Buc E, Delmas J, Gibold L, Sauvanet P, Darcha C, Dechelotte P, Bonnet M, et al. Bacterial genotoxin colibactin promotes colon tumour growth by inducing a senescence-associated secretory phenotype. Gut. 2014;63(12):1932-42.

130. Dalmasso G, Cougnoux A, Delmas J, Darfeuille-Michaud A, Bonnet R. The bacterial genotoxin colibactin promotes colon tumor growth by modifying the tumor microenvironment. Gut Microbes. 2014;5(5):675-80.

131. Toprak NU, Yagci A, Gulluoglu BM, Akin ML, Demirkalem P, Celenk T, Soyletir $\mathrm{G}$. A possible role of Bacteroides fragilis enterotoxin in the aetiology of colorectal cancer. Clin Microbiol Infect. 2006;12(8):782-6.

132. Chung L, Orberg ET, Geis AL, Chan JL, Fu K, DeStefano Shields CE, Dejea CM, Fathi P, Chen J, Finard BB, et al. Bacteroides fragilis Toxin Coordinates a Pro-carcinogenic Inflammatory Cascade via Targeting of Colonic Epithelial Cells. Cell Host \& Microbe. 2018;23(3):421.

133. Mima K, Nishihara R, Qian ZR, Cao Y, Sukawa Y, Nowak JA, Yang J, Dou R, Masugi $Y$, Song $M$, et al. Fusobacterium nucleatum in colorectal carcinoma tissue and patient prognosis. Gut. 2016;65(12):1973-80.

134. Rubinstein MR, Wang X, Liu W, Hao Y, Cai G, Han YW. Fusobacterium nucleatum promotes colorectal carcinogenesis by modulating E-cadherin/ beta-catenin signaling via its FadA adhesin. Cell host \& microbe. 2013;14(2):195-206.

135. Chen Y, Peng Y, Yu J, Chen T, Wu Y, Shi L, Li Q, Wu J, Fu X. Invasive Fusobacterium nucleatum activates beta-catenin signaling in colorectal cancer via a TLR4/P-PAK1 cascade. Oncotarget. 2017;8(19):31802-14.

136. Fardini $Y$, Wang $X$, Temoin S, Nithianantham S, Lee D, Shoham M, Han YW. Fusobacterium nucleatum adhesin FadA binds vascular endothelial cadherin and alters endothelial integrity. Mol Microbiol. 2011;82(6):1468-80.

137. Hilsden RJ, Meddings JB, Sutherland LR. Intestinal permeability changes in response to acetylsalicylic acid in relatives of patients with Crohn's disease. Gastroenterology. 1996;110(5):1395-403.

138. D'Inca R, Annese V, di Leo V, Latiano A, Quaino V, Abazia C, Vettorato MG, Sturniolo GC. Increased intestinal permeability and NOD2 variants in familial and sporadic Crohn's disease. Aliment Pharmacol Ther. 2006;23(10):1455-61.

139. Peeters M, Geypens B, Claus D, Nevens H, Ghoos Y, Verbeke G, Baert F, Vermeire $S$, Vlietinck R, Rutgeerts P. Clustering of increased small intestinal permeability in families with Crohn's disease. Gastroenterology. 1997;113(3):802-7.

140. Schmitz H, Barmeyer C, Fromm M, Runkel N, Foss HD, Bentzel CJ, Riecken EO, Schulzke JD. Altered tight junction structure contributes to the impaired epithelial barrier function in ulcerative colitis. Gastroenterology. 1999:116(2):301-9.

141. Arslan G, Atasever T, Cindoruk M, Yildirim IS. (51)CrEDTA colonic permeability and therapy response in patients with ulcerative colitis. Nucl Med Commun. 2001;22(9):997-1001.

142. Buning C, Geissler N, Prager M, Sturm A, Baumgart DC, Buttner J, Buhner S, Haas $V$, Lochs $\mathrm{H}$. Increased small intestinal permeability in ulcerative colitis: rather genetic than environmental and a risk factor for extensive disease? Inflamm Bowel Dis. 2012;18(10):1932-9.
143. Tibble JA, Sigthorsson G, Bridger S, Fagerhol MK, Bjarnason I. Surrogate markers of intestinal inflammation are predictive of relapse in patients with inflammatory bowel disease. Gastroenterology. 2000;119(1):15-22.

144. Jorgensen J, Ranlov PJ, Bjerrum PJ, Diemer H, Bisgaard K, Elsborg L. Is an increased intestinal permeability a valid predictor of relapse in Crohn disease? Scand J Gastroenterol. 2001;36(5):521-7.

145. Madsen KL, Malfair D, Gray D, Doyle JS, Jewell LD, Fedorak RN. Interleukin-10 gene-deficient mice develop a primary intestinal permeability defect in response to enteric microflora. Inflamm Bowel Dis. 1999;5(4):262-70.

146. Olson TS, Reuter BK, Scott KG, Morris MA, Wang XM, Hancock LN, Burcin TL, Cohn SM, Ernst PB, Cominelli F, et al. The primary defect in experimental ileitis originates from a nonhematopoietic source. J Exp Med. 2006;203(3):541-52.

147. Nenci A, Becker C, Wullaert A, Gareus R, van LG, Danese S, Huth M, Nikolaev A, Neufert C, Madison B, et al. Epithelial NEMO links innate immunity to chronic intestinal inflammation. Nature. 2007:446(7135):557-61.

148. Hermiston ML, Gordon J. Inflammatory bowel disease and adenomas in mice expressing a dominant negative $\mathrm{N}$-cadherin. Science. 1995;270(5239):1203-7.

149. Nighot P, Al-Sadi R, Rawat M, Guo S, Watterson DM, Ma T. Matrix metalloproteinase 9-induced increase in intestinal epithelial tight junction permeability contributes to the severity of experimental DSS colitis. Am J Physiol Gastrointest Liver Physiol. 2015;309(12):G988-97.

150. Liu X, Xu J, Mei Q, Han L, Huang J. Myosin light chain kinase inhibitor inhibits dextran sulfate sodium-induced colitis in mice. Dig Dis Sci. 2013;58(1):107-14

151. Lee TC, Huang YC, Lu YZ, Yeh YC, Yu LC. Hypoxia-induced intestinal barrier changes in balloon-assisted enteroscopy. J Physiol. 2017;596(15):13.

152. Wei SC, Yang-Yen HF, Tsao PN, Weng MT, Tung CC, Yu LCH, Lai LC, Hsiao $\mathrm{JH}$, Chuang EY, Shun CT, et al. SHANK3 Regulates Intestinal Barrier Function Through Modulating ZO-1 Expression Through the PKCepsilon-dependent Pathway. Inflamm Bowel Dis. 2017:23(10):1730-40.

153. Lu YZ, Huang CY, Huang YC, Lee TC, Kuo WT, Pai YC, Yu LC. Tumor Necrosis Factor alpha-Dependent Neutrophil Priming Prevents Intestinal Ischemia/ Reperfusion-Induced Bacterial Translocation. Dig Dis Sci. 2017.

154. Swidsinski A, Ladhoff A, Pernthaler A, Swidsinski S, Loening-Baucke V, Ortner M, Weber J, Hoffmann U, Schreiber S, Dietel M, et al. Mucosal flora in inflammatory bowel disease. Gastroenterology. 2002;122(1):44-54

155. Sobieszczanska BA, Duda-Madej AB, Turniak MB, Franiczek R, Kasprzykowska U, Duda AK, Rzeszutko M, Iwanczak B. Invasive properties, adhesion patterns and phylogroup profiles among Escherichia coli strains isolated from children with inflammatory bowel disease. Adv Clin Exp Med 2012; 21:591-9

156. Reuter BK, Pizarro TT. Mechanisms of tight junction dysregulation in the SAMP1/YitFc model of Crohn's disease-like ileitis. Ann N Y Acad Sci. 2009;1165:301-7.

157. Su L, Shen L, Clayburgh DR, Nalle SC, Sullivan EA, Meddings JB, Abraham C, Turner JR. Targeted Epithelial Tight Junction Dysfunction Causes Immune Activation and Contributes to Development of Experimental Colitis. Gastroenterology. 2009;136(2):551-63.

158. Zeissig S, Burgel N, Gunzel D, Richter J, Mankertz J, Wahnschaffe U, Kroesen AJ, Zeitz M, Fromm M, Schulzke JD. Changes in expression and distribution of claudin 2, 5 and 8 lead to discontinuous tight junctions and barrier dysfunction in active Crohn's disease. Gut. 2007;56(1):61-72.

159. Oshitani N, Watanabe K, Nakamura S, Fujiwara Y, Higuchi K, Arakawa T. Dislocation of tight junction proteins without F-actin disruption in inactive Crohn's disease. Int J Mol Med. 2005;15(3):407-10.

160. Blair SA, Kane SV, Clayburgh DR, Turner JR. Epithelial myosin light chain kinase expression and activity are upregulated in inflammatory bowel disease. Lab Invest. 2006;86(2):191-201.

161. Boudeau J, Glasser AL, Julien S, Colombel JF, Darfeuille-Michaud A. Inhibitory effect of probiotic Escherichia coli strain Nissle 1917 on adhesion to and invasion of intestinal epithelial cells by adherent-invasive E. coli strains isolated from patients with Crohn's disease. Aliment Pharmacol Ther. 2003;18(1):45-56.

162. Lewis K, Lutgendorff F, Phan V, Soderholm JD, Sherman PM, McKay DM. Enhanced translocation of bacteria across metabolically stressed epithelia is reduced by butyrate. Inflamm Bowel Dis. 2010;16(7):1138-48. 
163. Wang A, Keita AV, Phan V, McKay CM, Schoultz I, Lee J, Murphy MP, Fernando M, Ronaghan N, Balce D, et al. Targeting mitochondria-derived reactive oxygen species to reduce epithelial barrier dysfunction and colitis. Am J Pathol. 2014;184(9):2516-27.

164. Clark E, Hoare C, Tanianis-Hughes J, Carlson GL, Warhurst G. Interferon gamma induces translocation of commensal Escherichia coli across gut epithelial cells via a lipid raft-mediated process. Gastroenterology. 2005;128(5):1258-67.

165. Smyth D, McKay CM, Gulbransen BD, Phan VC, Wang A, McKay DM. Interferon-gamma signals via an ERK1/2-ARF6 pathway to promote bacterial internalization by gut epithelia. Cell Microbiol. 2012;14(8):1257-70.

166. Wells CL, VandeWesterlo EM, Jechorek RP, Erlandsen SL. Effect of hypoxia on enterocyte endocytosis of enteric bacteria. Crit Care Med. 1996;24(6):985-91.

167. Wu LL, Chiu HD, Peng WH, Lin BR, Lu KS, Lu YZ, Yu LCH. Epithelial inducible nitric oxide synthase causes bacterial translocation by impairment of enterocytic tight junctions via intracellular signals of Rho-associated kinase and protein kinase C zeta. Critical Care Medicine. 2011;39:2087-98.

168. Saggioro A. Leaky gut, microbiota, and cancer: an incoming hypothesis. J Clin Gastroenterol. 2014;48(Suppl 1):S62-6.

169. Hansen TH, Gobel RJ, Hansen T, Pedersen O. The gut microbiome in cardiometabolic health. Genome Med. 2015;7(1):33.

170. Lewis JD, Chen EZ, Baldassano RN, Otley AR, Griffiths AM, Lee D, Bittinger K, Bailey A, Friedman ES, Hoffmann C, et al. Inflammation, Antibiotics, and Diet as Environmental Stressors of the Gut Microbiome in Pediatric Crohn's Disease. Cell Host \& Microbe. 2015;18(4):489-500.

171. Winter SE, Winter MG, Xavier MN, Thiennimitr P, Poon V, Keestra AM, Laughlin RC, Gomez G, Wu J, Lawhon SD, et al. Host-derived nitrate boosts growth of E. coli in the inflamed gut. Science. 2013;339(6120):708-11.

172. Winter SE, Lopez CA, Baumler AJ. The dynamics of gut-associated microbial communities during inflammation. EMBO Rep. 2013;14(4):319-27.

173. Albenberg L, Esipova TV, Judge CP, Bittinger $K$, Chen J, Laughlin A, Grunberg S, Baldassano RN, Lewis JD, Li H, et al. Correlation between intraluminal oxygen gradient and radial partitioning of intestinal microbiota. Gastroenterology. 2014;147(5):1055-63 e1058.

174. Denizot J, Sivignon A, Barreau F, Darcha C, Chan HF, Stanners CP, Hofman P, Darfeuille-Michaud A, Barnich N. Adherent-invasive Escherichia coli induce claudin-2 expression and barrier defect in CEABAC10 mice and Crohn's disease patients. Inflamm Bowel Dis. 2012;18(2):294-304.

175. Han X, Fink MP, Delude RL. Proinflammatory cytokines cause NO-dependent and -independent changes in expression and localization of tight junction proteins in intestinal epithelial cells. Shock. 2003;19(3):229-37.

176. Menconi MJ, Unno N, Smith M, Aguirre DE, Fink MP. Nitric oxide donorinduced hyperpermeability of cultured intestinal epithelial monolayers: role of superoxide radical, hydroxyl radical, and peroxynitrite. BiochimBiophysActa. 1998;1425(1):189-203.

177. Landy J, Ronde E, English N, Clark SK, Hart AL, Knight SC, Ciclitira PJ, Al-Hassi HO. Tight junctions in inflammatory bowel diseases and inflammatory bowel disease associated colorectal cancer. World J Gastroenterol. 2016;22(11):3117-26.

178. Marteyn B, Scorza FB, Sansonetti PJ, Tang C. Breathing life into pathogens: the influence of oxygen on bacterial virulence and host responses in the gastrointestinal tract. Cell Microbiol. 2011;13(2):171-6.

179. Green J, Rolfe MD, Smith LJ. Transcriptional regulation of bacterial virulence gene expression by molecular oxygen and nitric oxide. Virulence. 2014:5(8):794-809.

180. Mirzaei MK, Maurice CF. Menage a trois in the human gut: interactions between host, bacteria and phages. Nature Rev Microbiol. 2017;15(7):397-408.

181. De Sordi L, Lourenco M, Debarbieux L. "I will survive": A tale of bacteriophage-bacteria coevolution in the gut. Gut Microbes. 2018:1-18.

182. Allegretti J, Eysenbach LM, El-Nachef N, Fischer M, Kelly C, Kassam Z. The Current Landscape and Lessons from Fecal Microbiota Transplantation for Inflammatory Bowel Disease: Past, Present, and Future. Inflamm Bowel Dis. 2017;23(10):1710-7.

183. Costello SP, Soo W, Bryant RV, Jairath V, Hart AL, Andrews JM. Systematic review with meta-analysis: faecal microbiota transplantation for the induction of remission for active ulcerative colitis. Aliment Pharmacol Ther. 2017:46(3):213-24

184. Moayyedi P, Surette MG, Kim PT, Libertucci J, Wolfe M, Onischi C, Armstrong D, Marshall JK, Kassam Z, Reinisch W, et al. Fecal Microbiota Transplantation Induces Remission in Patients With Active Ulcerative Colitis in a Randomized Controlled Trial. Gastroenterology. 2015;149(1):102-9 e106.
185. Vaughn BP, Vatanen T, Allegretti JR, Bai A, Xavier RJ, Korzenik J, Gevers D, Ting A, Robson SC, Moss AC. Increased Intestinal Microbial Diversity Following Fecal Microbiota Transplant for Active Crohn's Disease. Inflamm Bowel Dis. 2016;22(9):2182-90.

186. Qazi T, Amaratunga T, Barnes EL, Fischer M, Kassam Z, Allegretti JR. The risk of inflammatory bowel disease flares after fecal microbiota transplantation: Systematic review and meta-analysis. Gut Microbes. 2017;8(6):574-88.

187. Fries W, Belvedere A, Vetrano S. Sealing the broken barrier in IBD: intestinal permeability, epithelial cells and junctions. Curr Drug Targets. 2013;14(12):1460-70.

188. Bischoff SC, Barbara G, Buurman W, Ockhuizen T, Schulzke JD, Serino M, Tilg $\mathrm{H}$, Watson A, Wells JM. Intestinal permeability--a new target for disease prevention and therapy. BMC Gastroenterol. 2014;14:189.

189. Lin KY, Peng SY, Chou CJ, Lee HS, Lin LC, Pan RY, Wu SC. Infusion of Porcine-Derived Amniotic Fluid Stem Cells for Treatment of Experimental Colitis in Mice. Chin J Physiol. 2017;60(6):345-52.

190. Motta JP, Bermudez-Humaran LG, Deraison C, Martin L, Rolland C, Rousset $P$, Boue J, Dietrich G, Chapman K, Kharrat P, et al. Food-grade bacteria expressing elafin protect against inflammation and restore colon homeostasis. Sci Transl Med. 2012;4(158):158ra144.

191. Carroll IM, Andrus JM, Bruno-Barcena JM, Klaenhammer TR, Hassan HM, Threadgill DS. Anti-inflammatory properties of Lactobacillus gasseri expressing manganese superoxide dismutase using the interleukin 10-deficient mouse model of colitis. Am J Physiol Gastrointest Liver Physiol. 2007;293(4):G729-38

192. Kashyap PC, Chia N, Nelson H, Segal E, Elinav E. Microbiome at the Frontier of Personalized Medicine. Mayo Clin Proc. 2017;92(12):1855-64.

193. Zmora N, Zeevi D, Korem T, Segal E, Elinav E. Taking it Personally: Personalized Utilization of the Human Microbiome in Health and Disease. Cell Host \& Microbe. 2016;19(1):12-20.

194. Nagpal R, Yadav H. Bacterial Translocation from the Gut to the Distant Organs: An Overview. Ann Nutr Metab. 2017;71(Suppl 1):11-6.

Ready to submit your research? Choose BMC and benefit from:

- fast, convenient online submission

- thorough peer review by experienced researchers in your field

- rapid publication on acceptance

- support for research data, including large and complex data types

- gold Open Access which fosters wider collaboration and increased citations

- maximum visibility for your research: over $100 \mathrm{M}$ website views per year

At $\mathrm{BMC}$, research is always in progress.

Learn more biomedcentral.com/submissions 